\title{
TGF-B1-induced cell growth arrest and partial differentiation is related to the suppression of Id1 in human hepatoma cells
}

\author{
BAZARRAGCHAA DAMDINSUREN ${ }^{1}$, HIROAKI NAGANO ${ }^{1}$, MOTOI KONDO $^{1}$, JAVZANDULAM NATSAG $^{2}$, \\ HIROYUKI HANADA ${ }^{3}$, MASATO NAKAMURA ${ }^{1}$, HIROSHI WADA ${ }^{1}$, HITOSHI KATO ${ }^{1}$, SHIGERU MARUBASHI ${ }^{1}$, \\ ATSUSHI MIYAMOTO ${ }^{1}$, YUTAKA TAKEDA ${ }^{1}$, KOJI UMESHITA $^{1}$, KEIZO DONO $^{1}$ and MORITO MONDEN ${ }^{1}$ \\ Departments of ${ }^{1}$ Surgery and ${ }^{2}$ Diagnostic Radiology, Graduate School of Medicine, Osaka University; \\ ${ }^{3}$ Department of Clinical Laboratory, Osaka University Hospital, Osaka, Japan
}

Received July 6, 2005; Accepted September 20, 2005

\begin{abstract}
Transforming growth factor beta 1 (TGF- $\beta 1)$ is a proposed regulator of Ids (inhibitors of DNA binding/differentiation) gene expression in epithelial cells. We previously reported that Id proteins are variously expressed in human hepatocellular carcinomas (HCC). However, the mechanism of regulation of Ids in HCC remains obscure. Here, we examined the relationship between Id 1 and TGF- $\beta 1$ in four HCC cell lines, and studied the changes in cell proliferation, cell cycle and differentiation. The four HCC cell lines expressed Id1, TGF- $\$ 1$ and their receptors at various levels. TGF- $\$ 1$ strongly inhibited the growth of $\mathrm{HuH7}$ cells, while the growth inhibition was moderate in PLC/PRF/5, and was not observed in HLE and HLF cell lines. TGF- $\beta 1$-induced growth inhibition in $\mathrm{HuH7}$ cells was associated with cell accumulation in the G1 phase and partial induction of differentiation (with reduction of AFP and AFP-L3). Induction by TGF- 11 dose-dependently suppressed Id1 expression in HuH7 cells; $1 \mathrm{ng} / \mathrm{ml}$ TGF- $\beta 1$ inhibited Id 1 by 84.0 and $78.6 \%$ that of the untreated control at transcriptional and protein levels, respectively. HLE and HLF cells, which did not exhibit a TGF- $\beta 1$ growth inhibitory effect, lacked TGF- $\beta$ receptors and Id 1 expression was not altered. In PLC/PRF/ 5 cells, Id 1 augmentation was not observed in response to TGF- $\beta 1$, indicating that TGF- $\beta 1$ induced growth inhibition was not related to Id1 in this cell line. Our results suggest that, in some HCC cells, the pathway of suppression of Id 1 by TGF- $\$ 1$ may be important in TGF-ß1-induced growth inhibition and partial differentiation.
\end{abstract}

Correspondence to: Dr Hiroaki Nagano, Department of Surgery, Graduate School of Medicine, Osaka University, E2, 2-2 Yamadaoka, Suita, Osaka 565-0871, Japan

E-mail: hnagano@surg2.med.osaka-u.ac.jp

Key words: TGF-ß1, Id1, HCC, proliferation, differentiation, cell cycle

\section{Introduction}

Transforming growth factor- $\beta 1$ (TGF- $\beta 1$ ) is a multifunctional cytokine that inhibits epithelial cell growth by binding to a heterodimeric receptor consisting of both type 1 (TGFßRI) and type 2 (TGFßRII) serine/threonine kinase receptors. TGF- $\beta 1$ binding and activation of the TGF- 31 receptor complex propagates intracellular signal transduction involving Smad proteins, which regulate numerous developmental and homeostatic processes by regulating gene expression $(1,2)$. Resistance to growth inhibition by TGF- $\beta 1$ has been considered an important step in tumorigenesis and contributes to the development of many tumor types $(3,4)$. Recently, Idl (inhibitors of DNA binding or differentiation) was revealed to be one of the direct TGF- $\$ 1$ target genes (5). Specifically in epithelial cells, Id1 expression can be inhibited through the TGF-ß1responsive Smad3-activated transcriptional repressor, ATF3, which binds to the ATF/CREB site on the Id promoter, repressing Smad-initiated transcription.

Id proteins are members of the helix-loop-helix (HLH) family of transcription factors and are involved in regulation of various cellular processes, including cellular differentiation and cell cycling, and important functions in oncogenesis (6-9). Generally, Ids inhibit cell differentiation and induce proliferation by inhibiting basic HLH-dependent expression of differentiation-linked genes or suppressing the cyclindependent kinase inhibitors. However, these functions vary among cell types. Several studies have revealed a role for Id proteins in primary human tumors. Furthermore, deregulated expression of Ids has been reported in several primary human tumors such as pancreatic, breast, ovarian, prostate and neuronal tumors, and in colorectal adenocarcinoma and squamous cell carcinomas (reviewed in refs. 7 and 10). We have previously reported that Id proteins are down-regulated in human hepatocellular carcinomas (HCC) and their expression is related to tumor differentiation (11). However, the mechanism of regulation of Ids in HCC is not understood.

HCC is the fifth most common malignancy worldwide, and is estimated to cause approximately half a million deaths every year (12). Although curative therapies, such as hepatic resection, liver transplantation and percutaneous ablation, have led to an improvement in the survival of patients with 
HCC, the majority of patients are diagnosed in the the inoperable, advanced stages of the disease and/or have recurrence or metastasis after therapy, and their prognosis remains extremely poor $(13,14)$. It is essential to understand the molecular regulation of hepatocarcinogenesis and progression of liver cancer to achieve an improvement in cure rates, and Id proteins are possible candidates for cancer therapy (10). The present study was designed to determine the relationship between Id 1 and TGF- $\beta 1$ in HCC cell lines, and their effects on hepatoma cell proliferation, cell cycle and differentiation.

\section{Materials and methods}

Cell lines, cultures and in vitro assays. Human HCC cell lines, $\mathrm{HuH7}$, PLC/PRF/5, HLE and HLF, were purchased from the Japanese Cancer Research Resources Bank (Tokyo, Japan). They were from different origins and had distinct characteristics; the first two were established from differentiated hepatomas and expressed hepatic marker proteins, while the latter two originated from undifferentiated HCC and did not express any hepatic marker proteins (15). The cells were maintained in Dulbecco's modified Eagle's medium (DMEM) supplemented with $10 \%$ fetal bovine serum (FBS), 100 units/ml penicillin and $100 \mu \mathrm{g} / \mathrm{ml}$ streptomycin at $37^{\circ} \mathrm{C}$ in a humidified incubator with $5 \% \mathrm{CO}_{2}$ in air. For experiments with TGF- 31 , the cells were seeded and the next day they were incubated in a medium containing the desired concentrations of human platelet-derived TGF- $\beta 1$ (R\&D, Minneapolis, MN). At the selected time-points, the cells were harvested and RNA or protein was performed for each experiment as described below. For morphological examination, the cells were studied under light microscopy (Olympus IMT-2; Olympus Corp., Tokyo).

RNA extraction and cDNA generation. Sub-confluent growing cells were washed twice with Dulbecco's phosphate-buffered saline (PBS), and total RNA extraction was performed with a single-step method using Trizol Reagent (Invitrogen, Carlsbad, CA). Purified RNA was quantified and assessed for purity by UV spectrophotometry. Complementary DNA (cDNA) was generated using avian myeloblastosis virus reverse transcriptase (Promega, Madison, WI) (16).

Quantitative PCR assay with Light Cycler ${ }^{\mathrm{TM}}$. Fluorescence PCR was performed using the Light Cycler ${ }^{\mathrm{TM}}$ (Roche Diagnostics, Mannheim, Germany) in a $10-\mu 1$ PCR reaction containing $0.2 \mu \mathrm{M}$ of each primer, 1x Light Cycler-Fast start DNA Master SYBR-Green I (Roche Diagnostics), $4 \mathrm{mM}$ $\mathrm{MgCl}_{2}$ and $2 \mu \mathrm{l}$ of cDNA as template. The primer pair sequences were obtained from published sequences of Id1 (17), TGF-ß1 (18), TGFßRI (19), TGFßRII (20) and ß-actin (21), and synthesized from commercial sources. The PCR conditions were as follows: one cycle of denaturing at $95^{\circ} \mathrm{C}$ for $10 \mathrm{~min}$, followed by 40 cycles of $95^{\circ} \mathrm{C}$ for $15 \mathrm{sec}, 65^{\circ} \mathrm{C}$ for $10 \mathrm{sec}$ and $72^{\circ} \mathrm{C}$ for $30 \mathrm{sec}$ (or annealing at $58^{\circ} \mathrm{C}$ for $\mathrm{B}$ actin), and a final extension at $72^{\circ} \mathrm{C}$ for $10 \mathrm{~min}$. Fluorescence was acquired at the end of each $72^{\circ} \mathrm{C}$ extension phase. The melting curves of final PCR products were analyzed after 40 cycles of PCR amplification by cooling the samples to $65^{\circ} \mathrm{C}$, increasing the temperature to $99^{\circ} \mathrm{C}$ at a rate of $0.1^{\circ} \mathrm{C} / \mathrm{sec}$, and monitoring the fluorescence at each $0.1^{\circ} \mathrm{C}$. Quantification data were analyzed using Light Cycler $^{\mathrm{TM}}$ analysis software (Roche Diagnostics) as recommended by the manufacturer. The standard curves for quantification of each mRNA were constructed by using serial dilutions of cDNA from most expressing cell lines. Expression of each mRNA was reported relative to $\beta$-actin.

Growth inhibitory assay. For drawing growth curves with TGF- 31 , the cells were uniformly seeded in 12-well dishes (4x10 4 cells/well for $\mathrm{HuH} 7,3 \times 10^{4}$ cells/well for PLC/PRF/5, $1.5 \times 10^{4}$ cells/well for HLE and HLF). The next day, the medium was replaced with fresh medium containing different concentrations of TGF- $\beta 1(0,0.1,1 \mathrm{ng} / \mathrm{ml})$ and this was repeated every $48 \mathrm{~h}$. On days $0,2,4$ and 6 after starting the treatment, adherent cells were harvested and counted using a Celltac semi-automatic analyzer (Nihon Kohden, Tokyo).

Cell-cycle analysis. Flow cytometric analysis was performed as described previously (22). Briefly, cells were washed twice with PBS and then fixed in $75 \%$ cold ethanol overnight and then washed and re-suspended in $1 \mathrm{ml}$ of PBS. After incubation for $30 \mathrm{~min}$ at $37^{\circ} \mathrm{C}$ in ribonuclease (Wako Pure Chemicals, Osaka, Japan; final concentration of $1 \mathrm{mg} / \mathrm{ml}$ ), propidium iodide (Sigma Chemical Co., St. Louis, MO; $0.1 \mathrm{mg} / \mathrm{ml}$ ) was added and incubated at $4^{\circ} \mathrm{C}$ for $30 \mathrm{~min}$. Samples were filtered through 44- $\mu \mathrm{m}$ nylon mesh, and data were acquired with a BD FACScan ${ }^{\mathrm{TM}}$ cell sorting system (Becton-Dickinson, San Jose, CA). Cell-cycle analysis was carried out using ModFIT software (Becton-Dickinson).

Determination of albumin, AFP and AFP-L3 proteins. Subconfluent growing cells were washed twice with cold PBS and collected by scraping. Protein lysates were centrifuged at $14000 \mathrm{rpm}$ for $15 \mathrm{~min}$ at $4^{\circ} \mathrm{C}$, and the supernatants were collected. Albumin was determined by turbidimetric immunoassay with autometric analyzer (Hitachi-7250, Hitachi, Tokyo) (23). $\alpha$-fetoprotein (AFP) was measured by chemiluminescence immunosorbent assay (SphereLife180, Wako Pure Chemical Industries, Osaka) (24). Lens culinaris agglutininreactive AFP (AFP-L3) was determined by liquid-phase binding assay (LiBASys, Wako) (25).

Western blot analysis. Sub-confluent growing cells were washed twice with ice-cold PBS and collected with a rubber scraper in ice-cold RIPA buffer [25 mM Tris (pH 7.5), $50 \mathrm{mM}$ $\mathrm{NaCl}, 0.5 \%$ sodium deoxycholate, $2 \%$ nonidet $\mathrm{P}-40,0.2 \%$ sodium dodecyl sulfate (SDS), $1 \mathrm{mM}$ phenylmethylsulfonyl fluoride and $500 \mathrm{KIE} / \mathrm{ml}$ 'Trasylol ${ }^{\circledR}$ ' proteinase-inhibitor (Bayer Leverkusen, Germany)]. The collected lysate was centrifuged at $14000 \mathrm{rpm}$ at $4^{\circ} \mathrm{C}$ for $14 \mathrm{~min}$, and the resulting supernatant was collected. The total protein concentration was determined using the Bradford protein assay (Bio-Rad, Hercules, CA) and Western blot analysis was performed as described in our previous study (11). The antibodies were used in dilutions of 1:100 for Id1 (sc-488; Santa Cruz Biotechnology, Santa Cruz, CA), 1:1000 for actin (A-2066; Sigma) and 1:2000 for secondary donkey anti-rabbit (NA934V; Amersham Biosciences, Buckingham-shire, UK) antibodies. Expression was evaluated by measuring the optical densities of Id1 protein 

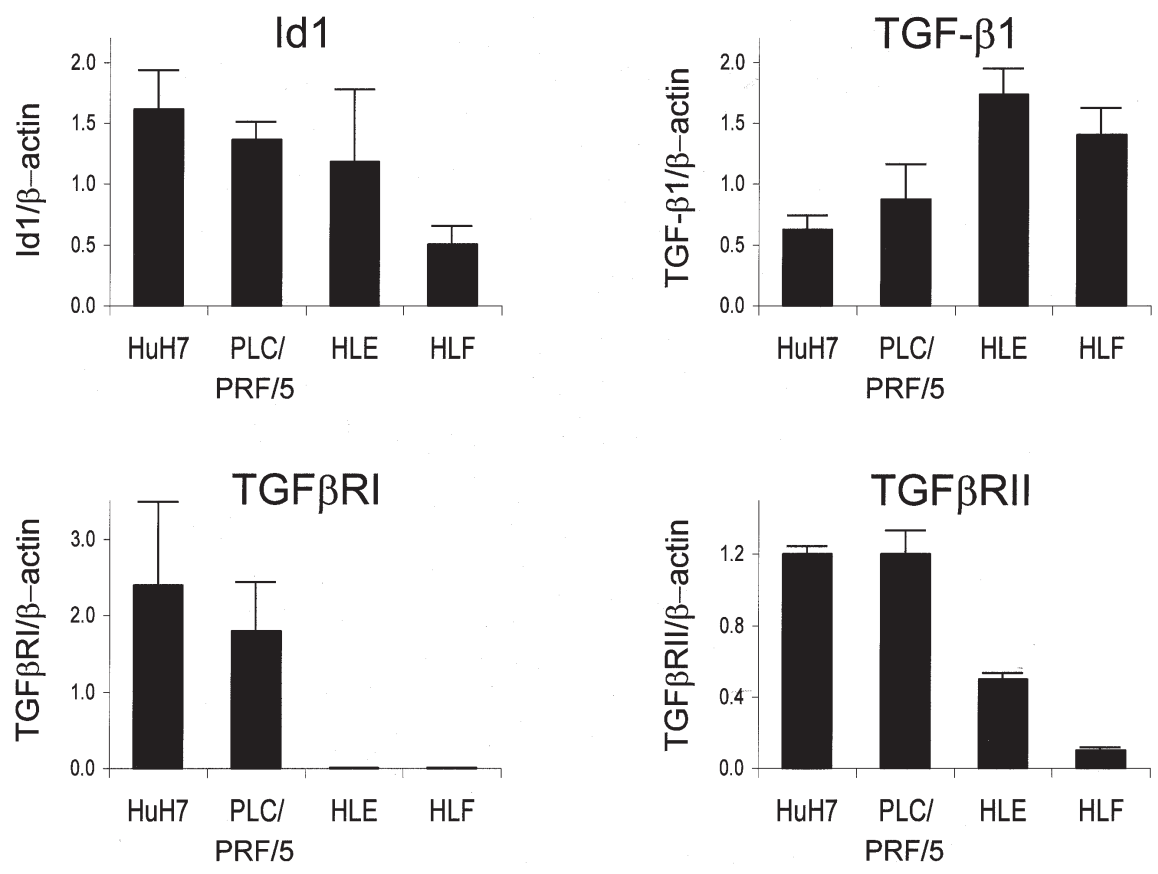

Figure 1. Expression of Id1, TGF-ß1 and TGF- $\beta 1$ receptors in HCC cell lines. Quantitative PCR assay using the Light Cycler ${ }^{\circledR}$ revealed that hepatoma cells expressed Id1 and TGF-ß1 at various levels. The expression of TGF-ßRs was higher in HuH7 and PLC/PRF/5 cells; however, HLE and HLF cells lacked TGF-ßRI and expressed TGF-ßRII at a low level. Values are expressed as mean \pm SD of four independent experiments (normalized with the copies of $\beta$-actin).
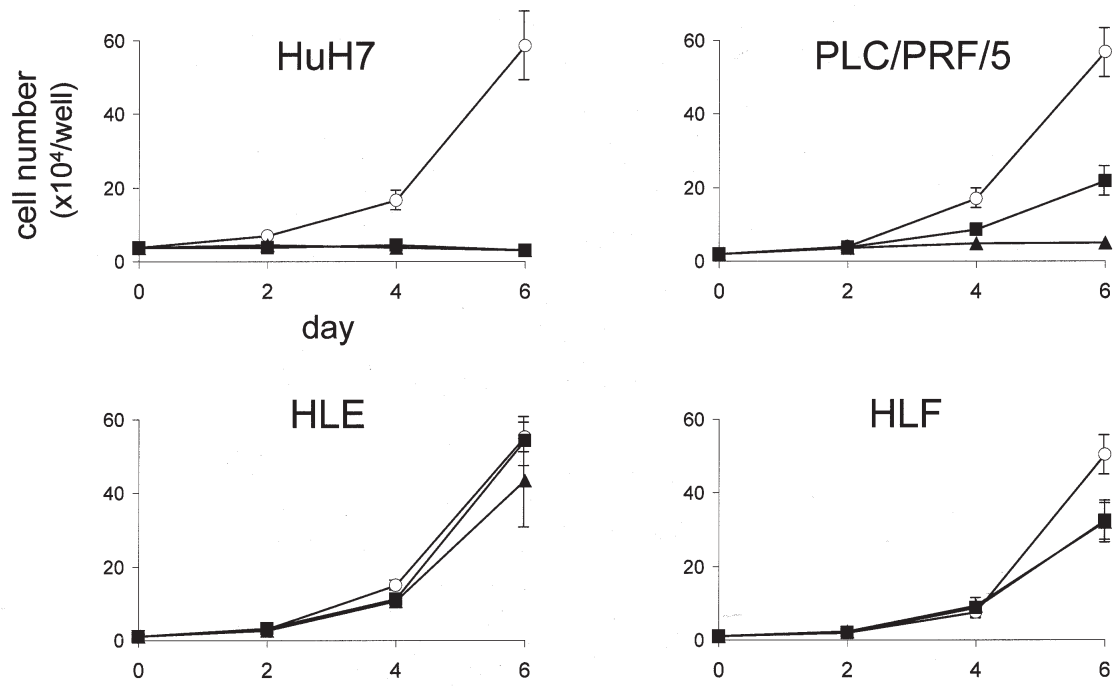

TGF- $\beta 1(1 \mathrm{ng} / \mathrm{ml})$

Figure 2. Growth curves of hepatoma cells cultured with or without TGF- $\beta 1$ for the initial 6 days. TGF- $\beta 1$ induced strong cell growth suppression in HuH7 cells and had a moderate effect on PLC/PRF/5 cells. However, HLE and HLF cells were resistant to TGF- $\beta 1$ treatment. Data represent mean \pm SD of three independent experiments.

bands, using the ImageJ1.33u software (National Institutes of Health, Bethesda, MD) and the expression value was calculated relative to that of actin.

Statistical analyses. Statistical analyses were performed using the StatView-5.0.1 program (SAS Institute Inc., Cary, NC). The unpaired t-test was used to examine the correlations between two variables. In all analyses, p-values $<0.05$ were considered statistically significant.

\section{Results}

Expression of Id1, TGF- $\beta 1$ and TGF- $\beta 1$ receptors in HCC cell lines. We first examined whether the four HCC cell lines expressed Id1, TGF-ß1 and TGFßRI/II. As shown in Fig. 1, quantitative PCR assay using the Light $\mathrm{Cycler}^{\circledR}$ revealed that the hepatoma cells expressed various levels of Id1, and the expression was higher in HuH7, PLC/PRF/5 and HLE cells. TGF-ß1 was also expressed at different levels, with lower levels 
A

\section{$\mathrm{HuH} 7$}
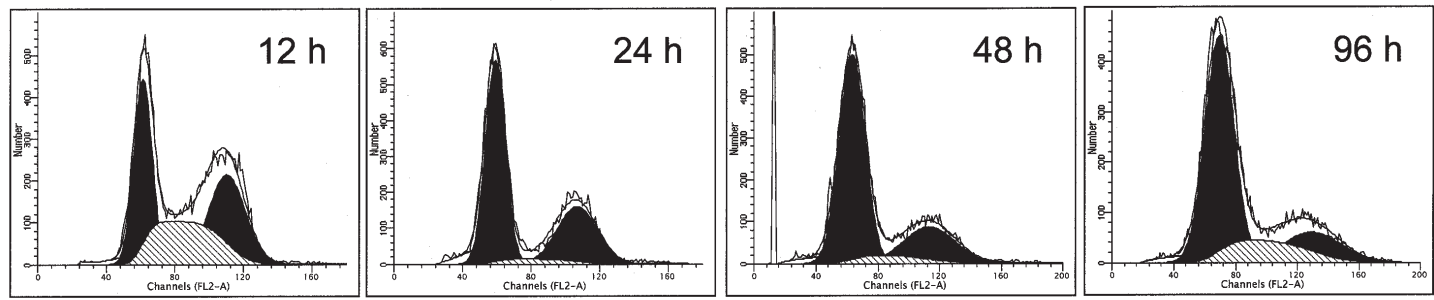

HLE
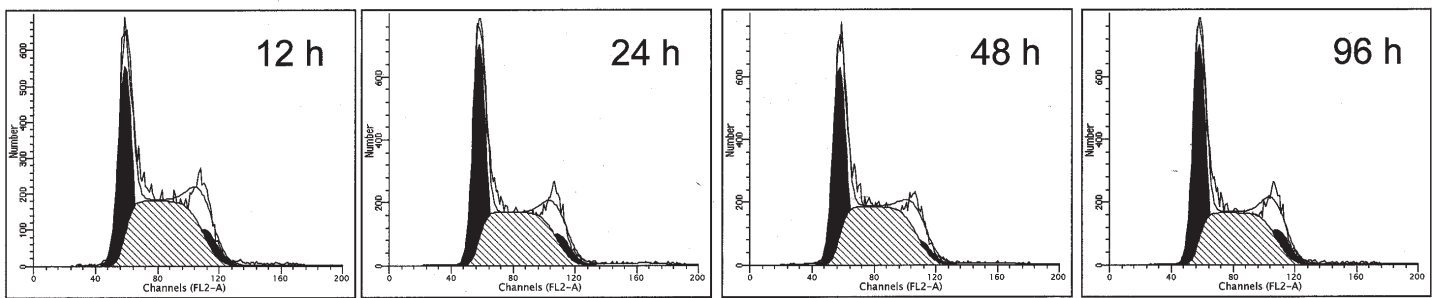

B

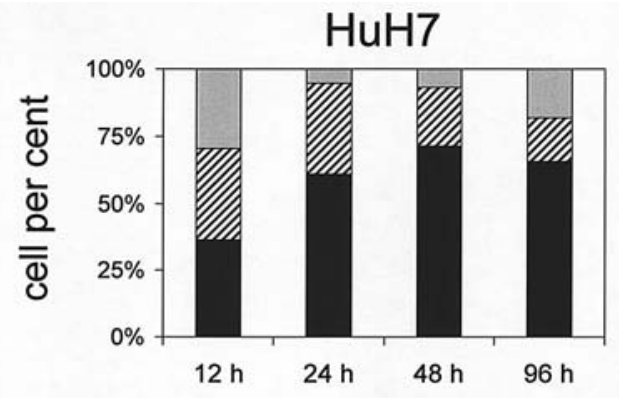

PLC/PRF/5

HLE

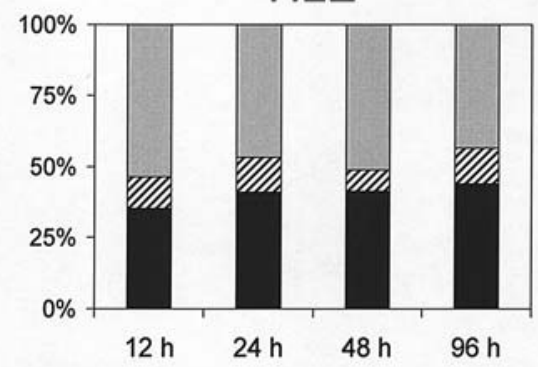

HLF

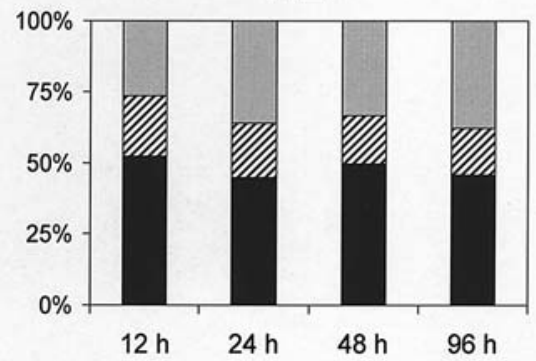

G1 phase $\mathbb{S}$ phase $\square$ G2 phase

Figure 3. Effect of TGF-ß1 on the cell cycle. Cell-cycle analysis was performed on cells treated with $1 \mathrm{ng} / \mathrm{ml}$ TGF- 31 for up to $96 \mathrm{~h}$; representative cell-cycle graphs of $\mathrm{HuH7}$ and HLE cell lines are shown in A, and data from three independent experiments are summarized in B. The percentage of HuH7 cells in G1 state stably increased from 36.4 to 60.8, 71.2 and 65.6\% after exposure to TGF- 31 . However, no changes in cell cycle were observed in HLE and HLF cells during the treatment, and the accumulation of cells in G1 phase returned to the former cell-cycle balance for PLC/PRF/5 cells.

in $\mathrm{HuH} 7$ and PLC/PRF/5 cells. HuH7 and PLC/PRF/5 were positive for both TGFßRI and II, while HLE and HLF cells were negative for TGFßRI and only had a low level of TGFßRII.

Effect of exogenous TGF- $\beta 1$ on cell proliferation and the cell cycle. For the examination of cell growth, the cell lines were treated with different concentrations of TGF- $\beta 1$ and viable cells were counted every 48 h for 6 days. As shown in Fig. 2, TGF- $\beta 1$ treatment resulted in a reduced cell growth rate in $\mathrm{HuH} 7$ and PLC/PRF/5 cells at the concentrations tested. In
$\mathrm{HuH} 7$ cells in particular, a low concentration $(0.1 \mathrm{ng} / \mathrm{ml})$ of TGF-31 stopped cell proliferation. In PLC/PRF/5 cells, the TGF-ß1-induced growth inhibition was less than in $\mathrm{HuH7}$ cells and exhibited dose- and exposure time-dependency. On the other hand, HLE and HLF cells did not respond to TGF-B1 treatment.

Cell-cycle analysis showed that the number of $\mathrm{HuH} 7$ cells in G1 phase was stably increased with exposure to $1 \mathrm{ng} / \mathrm{ml}$ TGF- 1 1; however, no cell-cycle changes were observed in HLE and HLF cells during the treatment (Fig. 3A and data not shown). The percentage of $\mathrm{HuH} 7$ cells in G1 state was 


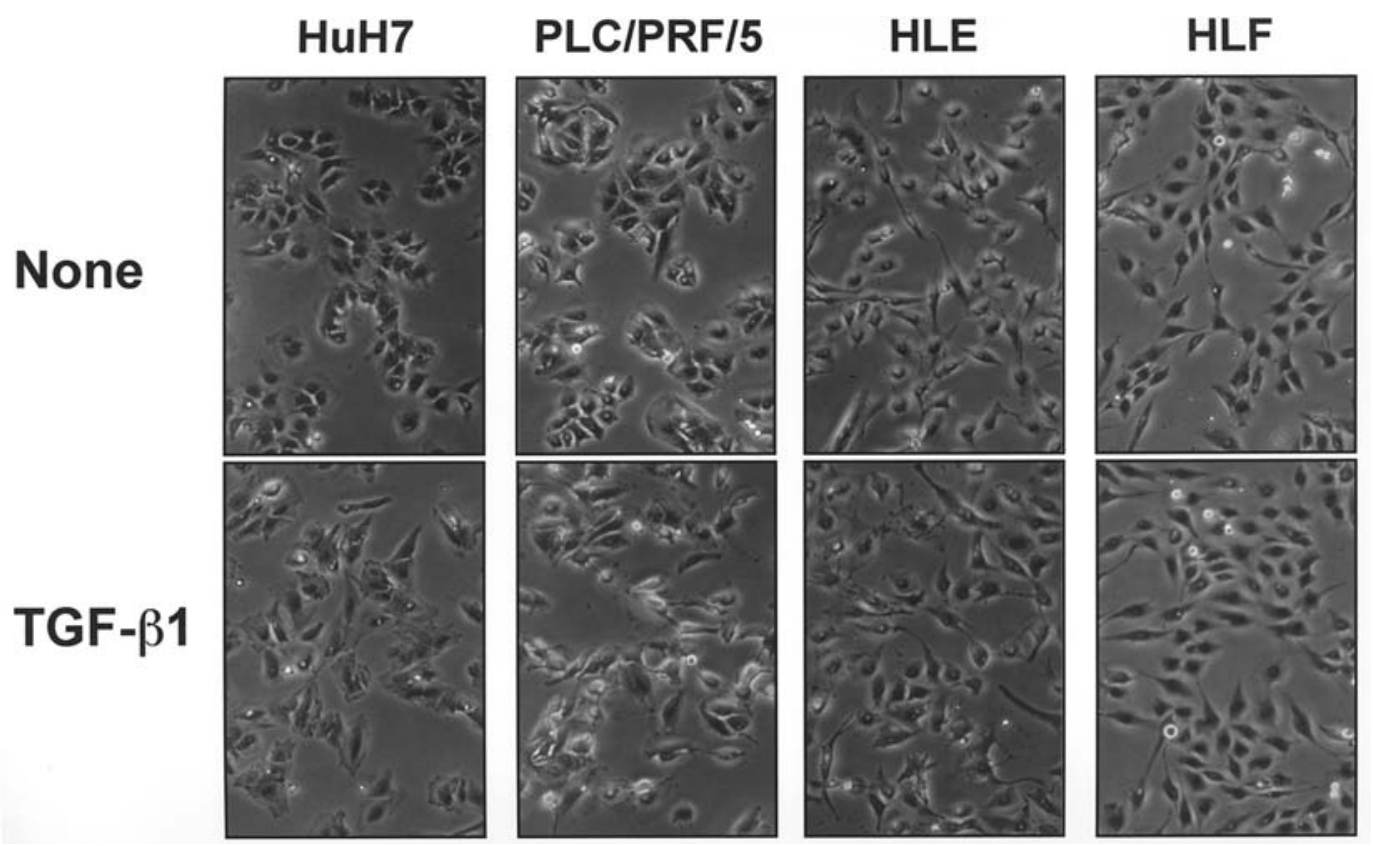

Figure 4. Effect of TGF- $\beta 1$ ( $1 \mathrm{ng} / \mathrm{ml})$ on cell morphology. The cells were observed under light microscopy after exposure to $1 \mathrm{ng} / \mathrm{ml}$ TGF- $\beta 1$ or without TGF- $\beta 1$ for $48 \mathrm{~h}$. TGF- $\beta 1$ treatment resulted in the enlargement and flattening of HuH7 cells, and increased their nucleus:cytoplasm ratio. No such visible changes were observed in other cell lines. Photos were taken under x60 magnification.
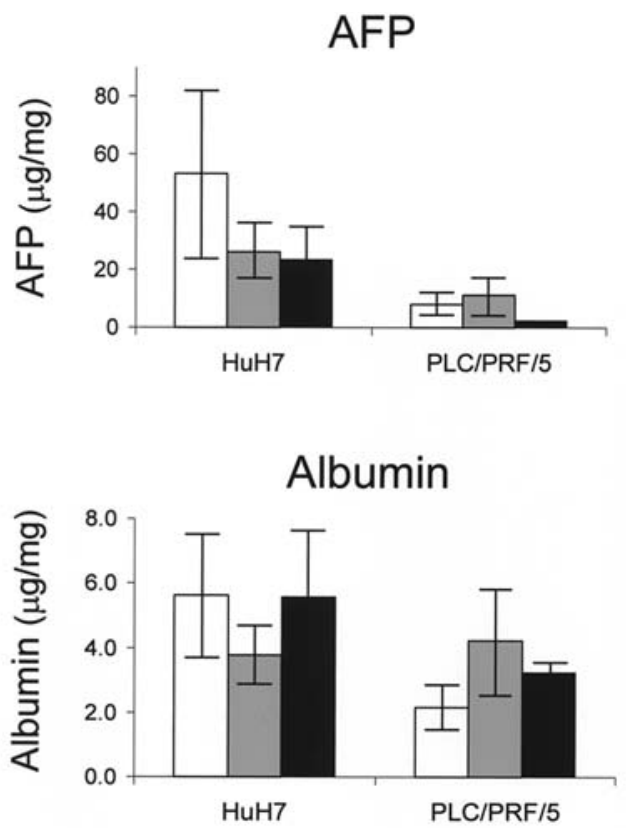
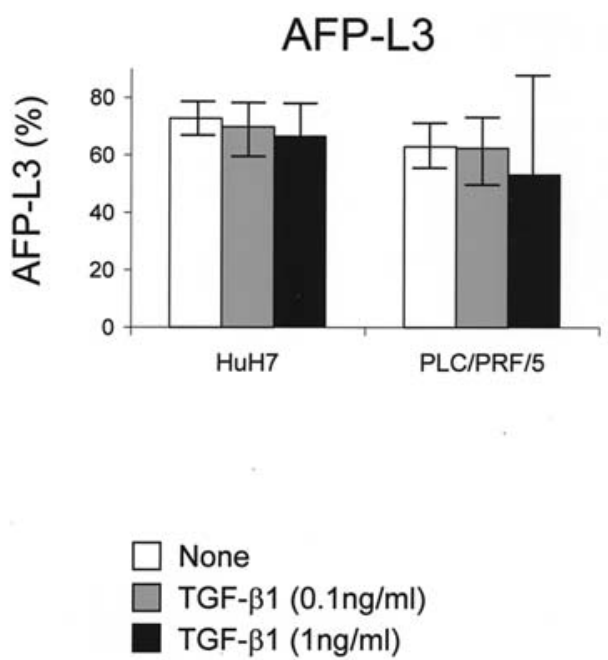

Figure 5. Effects of TGF- 31 on AFP, AFP-L3 and albumin expression in hepatoma cell lines. The cells were cultured with desired concentrations of TGF- 31 for $48 \mathrm{~h}$ and protein expression was measured in whole cell lysates by protein assays as described in Materials and methods. HLE and HLF cell lines do not express these proteins (data not shown). In the HuH7 cells TGF- 11 exposure decreased the expression of both AFP and AFP-L3. In PLC/PRF/5 cells, the expression of AFP-L3 decreased. The changes were not statistically significant. Values are expressed as mean \pm SD of three independent experiments.

$36.4,60.8,71.2$ and $65.6 \%$, respectively, at each time-point of observation, while for PLC/PRF/5 cells the accumulation of cells in $\mathrm{G} 1$ phase returned to the former cell-cycle balance, and the cell cycle of HLE and HLF cell lines was constant during the treatment (Fig. 3B).

Effect of TGF- $\beta 1$ on cell differentiation. Morphological examination of TGF-ß1-treated cells showed enlargement and flattening of $\mathrm{HuH} 7$ cells after exposure to $1 \mathrm{ng} / \mathrm{ml}$ TGF- 31 for $48 \mathrm{~h}$, together with an increase in nucleus:cytoplasm ratio (Fig. 4), which perhaps resembles the morphological characteristics of cells undergoing maturation. These changes correlated with exposure time and concentrations of TGF- 31 (data not shown). In other cell lines, no visible changes were observed during TGF- $\beta 1$ treatment.

To clarify the morphological changes and the effect of TGF- $\beta 1$ on differentiation of hepatoma cells, the expression of albumin, and AFP and AFP-L3 proteins was studied because 
A

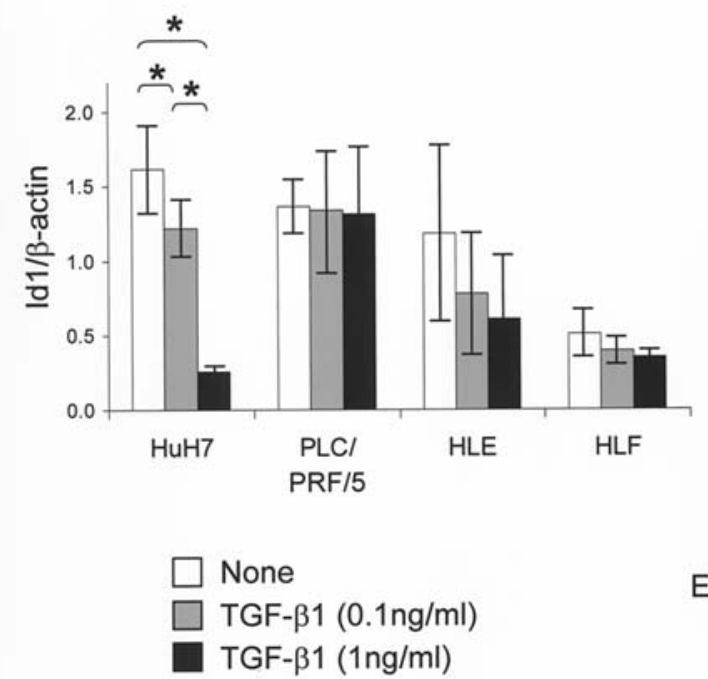

B

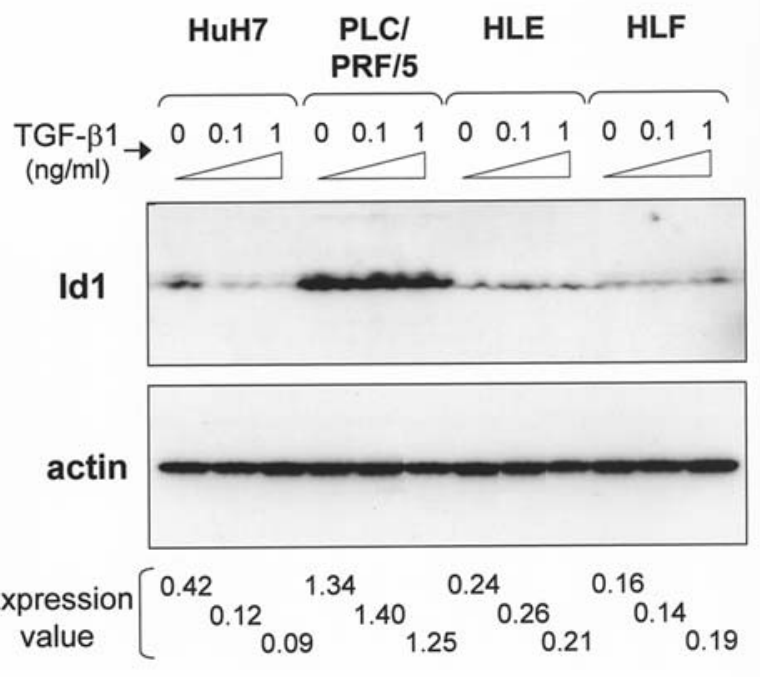

Figure 6. Effect of TGF- $\beta 1$ on Id1 expression. Cells were treated with TGF- $\beta 1(0,0.1$ and $1 \mathrm{ng} / \mathrm{ml})$ and the RNA and protein expression levels of Id1 were examined after $48 \mathrm{~h}$. (A) Quantitative PCR analysis revealed that Id1 mRNA expression in HuH7 cells was suppressed dose-dependently by TGF- 11 treatment (by $24.6,84.0 \%$ of control). Data represent mean $\pm \mathrm{SD}$ of three independent experiments. ${ }^{*} \mathrm{P}<0.05$ by the unpaired t-test. (B) Western blot analysis showed that Id1 protein expression was also suppressed in HuH7 cells; however, no significant change of Id1 expression was observed in other cell lines. The expression value was calculated relative to that of actin. Data are representative of similar results of repeated experiments.

AFP and particularly AFP-L3 are known to be specific for transformed hepatocytes with a high grade of malignancy, and albumin secretion is recognized as one of the phenotypes specific for mature hepatocytes $(26,27)$. However, HLE and HLF cell lines did not express those proteins (data not shown). As shown in Fig. 5, at $48 \mathrm{~h}$ post exposure to TGF-ß1, a dosedependent decrease in both AFP and AFP-L3 expression was observed in the treated $\mathrm{HuH} 7$ cells. In PLC/PRF/5, a tendency toward increased albumin expression and decreased AFP and AFP-L3 was observed. However, these changes were not statistically different.

Effect of exogenous TGF- $\beta 1$ on IdI expression. To study the effect of TGF- $\beta 1$ on the expression of Id1, cells were treated with TGF- $\beta 1(0,0.1$ and $1 \mathrm{ng} / \mathrm{ml})$ and the RNA and protein expression levels of Id 1 were examined after $48 \mathrm{~h}$. In the $\mathrm{HuH} 7$ cell line, which was most sensitive to TGF-ß1, Id1 expression was suppressed by TGF- $\beta 1$ in a dose-dependent manner at both the transcriptional and protein levels. However, no significant change in Id1 expression was observed in other cell lines (Fig. 6). In HuH7 cells, Id1 mRNA expression was decreased by 24.6 and $84.0 \%$, and protein expression was decreased by 71.2 and $78.6 \%$, respectively, by each dose of TGF- 11 compared to untreated control. This decrease was dependent on exposure time (data not shown).

Considered together, the above results suggest that TGF- $ß 1$ induced growth inhibition of $\mathrm{HuH} 7$ cells may be the result of cell-cycle arrest in G1 phase and partial re-differentiation, which may be associated with down-regulation of Id 1 . However, in PLC/PRF/5 cells, the growth inhibition did not involve the TGF- $\beta 1-I d 1$ pathway, and the interruption of TGF- $\beta 1$ signaling in HLE and HLF cells resulted in a resistance to TGF- $\beta 1$ effects.

\section{Discussion}

Although Id proteins have been shown to function as negative regulators of differentiation, and are up-regulated in major cancers (reviewed in refs. 7 and 10), our study revealed that Id proteins were down-regulated in human HCCs, and their expression levels were related to tumor differentiation (11). Our results and data obtained by gene expression profiling analysis are comparable to those of a previous report (28 and our unpublished data). The discrepancy between Ids expression in HCC and other tumors and the regulation of Id proteins in $\mathrm{HCC}$ are issues that remain unclarified at present. Therefore, the present study was performed in an effort to investigate the relationship and regulation of Id 1 protein with TGF- $\$ 1$ in HCC cells, and the effects on cell proliferation, cell cycle and differentiation.

Recent studies have revealed that $I d s$ are direct target genes of TGF- $\beta 1(29,30)$. TGF- $\beta 1$ is overexpressed in HCCs compared with non-tumor liver tissue and is expressed at higher levels in less-differentiated tumors, which is distinct from other malignancies $(31,32)$. This expression pattern of TGF- $\beta 1$ was the inverse of our previous findings with Ids, which led us to speculate on the possibility of suppression of Ids by TGF-ß1 in HCC (11).

TGF- $\beta 1$ is one of the most well known and potent inhibitors of epithelial cell growth (1). The autocrine and paracrine effects of TGF- $\beta 1$ on tumor cells and the tumor micro-environment exert both positive and negative influences on cancer development. Accordingly, the TGF- $\$ 1$ signaling pathway has been considered as both a tumor suppressor pathway and a promoter of tumor progression and invasion (2). In the liver, TGF- $\beta 1$ is mainly produced by non-parenchymal cells and acts as a paracrine negative regulator of hepatocyte proliferation $(33,34)$. 
However, human HCC displayed significant intracellular expression of TGF- $\$ 1$ protein, whereas no staining for TGF- 31 has been detected in hepatocytes of normal liver $(31,32)$. Our present results showed that HCC cell lines expressed various levels of TGF- 31 as well as Id1 mRNA. Furthermore, exogenous induction by TGF- 11 suppressed Id1 expression in $\mathrm{HuH} 7$ cells in a dose-dependent manner, at both transcriptional and protein levels (Fig. 6). In addition, our results revealed that the decrease in Id1 expression was comparable with TGF-31-induced growth inhibition (Figs. 2 and 6), which resulted from the arrest of cell-cycle progression from G1 to $S$ phase in this cell line (Fig. 3). Since Id proteins are involved in the regulation of cellular differentiation, proliferation and the cell cycle, we hypothesize that the reduced expression of Id1 may contribute to growth and differentiation changes in $\mathrm{HuH7}$ cells. However, this was not true for growth inhibition by TGF- 31 in PLC/PRF/5 cells. The reason for this difference in suppression of Id1 by TGF- 11 in $\mathrm{HuH} 7$ and PLC/PRF/5 cells, when TGF- $\beta 1$ induces growth arrest in both cell lines, remains unclear. It may relate to differences in various molecules specific to the TGF- $31-I d 1$ pathway; for instance, the expression of ATF3 was 1.74-fold less in PLC/PRF/5 cells than in HuH7 cells (unpublished data). Our results also revealed that HLE and HLF cell lines did not exhibit the TGF- 11 effect, and Id1 expression was not altered in these lines. These cells lacked TGF-ßRs (Fig. 1), which might explain the interruption of the TGF-B1-Smad signaling pathway in these cell lines.

The molecular pathway for the role of Ids in cell proliferation might involve cyclin-dependent kinase inhibitors, such as $\mathrm{p} 16^{\mathrm{INK} 4 \mathrm{a}}, \mathrm{p} 21^{\mathrm{WAF} 1}, \mathrm{p} 27^{\mathrm{KIP} 1}$ and retinoblastoma proteins that are suppressed by Id1 $(7,9)$. Similarly, this was shown in liver cancer cells where the overexpression of Id1 induced cell proliferation through inactivation of the $\mathrm{p} 16^{\mathrm{INK} 4 \mathrm{a}} /$ retinoblastoma pathway (35). Id expression was also enhanced during cellular proliferation and in response to mitogenic stimuli $(36,37)$. Our unpublished data show an increase of Id with serum addition in medium, and it is well known that FBS is a mitogenic stimulator in cell cultures. Similar results with induction of Ids by serum were previously described in studies on breast and pancreatic cancer cell lines $(38,39)$. In vivo, in experiments on rats, Id 1 was activated from $6 \mathrm{~h}$ after partial hepatectomy, which is used as a model for stimulation of hepatocyte proliferation (40).

Id proteins function as inhibitors of cell differentiation. Our results showed a possible link between the inhibition of Id1 by TGF- 31 and activation of cell differentiation in $\mathrm{HuH7}$ cells; i.e. the morphological changes toward maturation and decrease of AFP and AFP-L3 expression (Figs. 4-6). However, the changes in these markers were not statistically significant, which might reflect the short observation time. To confirm these findings, we also studied the effect of acyclic retinoid (all trans-3,7,11,15-tetramethyl-2,4,6,10,14-hexadecapentaenoic acid; Nikken Chemicals Co., Tokyo) on Id expression. Acyclic retinoid demonstrates the potential to induce the differentiation of human hepatoma cell lines (41). The treatment of HCC cells with acyclic retinoid inhibited the expression of Id1, which is associated with up-regulation of mature hepatocyte-specific genes, such as albumin, and down-regulation of AFP gene expression (unpublished data).
Collectively, our findings suggest that TGF-ß1-induced growth inhibition (involving cell-cycle arrest in G1-S transition and partial re-differentiation) of TGF-ßR-positive HCC cell lines may be associated with down-regulation of Id1, at least in some cells. However, in other cell lines, TGF- $\beta 1$ effects were less powerful and did not involve the TGF-B1-Id1 pathway. Our previous findings in an in vivo study, showing that Id1 correlates with HCC differentiation (11), might be an indirect outcome of TGF- $\$ 1$ in liver cancer. Moreover, the results suggest the possible roles of Id1 protein in the carcinogenesis and development of HCCs under direct TGF- 31 control. Finally, our data imply a possible strategy for the treatment or prevention of human HCC, through targeting Ids with TGF-ß1 (10).

In conclusion, our results suggest that, in some $\mathrm{HCC}$ cells, the pathway of suppression of Id 1 by TGF- $\beta 1$ may be important in TGF-B1-induced growth inhibition and partial re-differentiation.

\section{Acknowledgements}

This study was supported by a Grant-in-Aid for Scientific Research provided by the Ministry of Education, Culture, Sports, Science and Technology, Japan. B.D. is a postdoctoral fellow supported by Japan Society for the Promotion of Science.

\section{References}

1. Massague J: How cells read TGF-beta signals. Nat Rev Mol Cell Biol 1: 169-178, 2000.

2. Derynck R, Akhurst RJ and Balmain A: TGF-beta signaling in tumor suppression and cancer progression. Nat Genet 29: 117-129, 2001.

3. Jakowlew SB, Moody TW, You L and Mariano JM: Reduction in transforming growth factor-beta type II receptor in mouse lung carcinogenesis. Mol Carcinog 22: 46-56, 1998.

4. Lu SL, Zhang WC, Akiyama Y, Nomizu T and Yuasa Y: Genomic structure of the transforming growth factor beta type II receptor gene and its mutations in hereditary non-polyposis colorectal cancers. Cancer Res 56: 4595-4598, 1996.

5. Coppe JP, Smith AP and Desprez PY: Id proteins in epithelial cells. Exp Cell Res 285: 131-145, 2003.

6. Ruzinova MB and Benezra R: Id proteins in development, cell cycle and cancer. Trends Cell Biol 13: 410-418, 2003.

7. Norton JD: ID helix-loop-helix proteins in cell growth, differentiation and tumorigenesis. J Cell Sci 113: 3897-3905, 2000 .

8. Benezra R, Davis RL, Lockshon D, Turner DL and Weintraub H: The protein Id: a negative regulator of helix-loop-helix DNA binding proteins. Cell 61: 49-59, 1990.

9. Zebedee $\mathrm{Z}$ and Hara E: Id proteins in cell cycle control and cellular senescence. Oncogene 20: 8317-8325, 2001.

10. Fong S, Debs RJ and Desprez PY: Id genes and proteins as promising targets in cancer therapy. Trends Mol Med 10: 387-392, 2004.

11. Damdinsuren B, Nagano H, Kondo M, Yamamoto H, Hiraoka N, Yamamoto T, Marubashi S, Miyamoto A, Umeshita K, Dono K, Nakamori S, Wakasa K, Sakon M and Monden M: Expression of Id proteins in human hepatocellular carcinoma: relevance to tumor dedifferentiation. Int J Oncol 26: 319-327, 2005.

12. El-Serag HB: Hepatocellular carcinoma: an epidemiologic view. J Clin Gastroenterol 35: S72-S78, 2002.

13. Befeler AS and Di Bisceglie AM: Hepatocellular carcinoma: diagnosis and treatment. Gastroenterology 122: 1609-1619, 2002

14. Llovet JM, Burroughs A and Bruix J: Hepatocellular carcinoma. Lancet 362: 1907-1917, 2003.

15. Miyazaki M and Namba M: Hepatocellular carcinomas. In: Atlas of Human Tumor Cell Lines. Hay RJ, Park JG and Gazdar A (eds). Academic Press, San Diego, Tokyo, pp185-212, 1994. 
16. Chomczynski P and Sacchi N: Single-step method of RNA isolation by acid guanidinium thiocyanate-phenol-chloroform extraction. Anal Biochem 162: 156-159, 1987.

17. Jaleco AC, Stegmann AP, Heemskerk MH, Couwenberg F, Bakker AQ, Weijer K and Spits H: Genetic modification of human B-cell development: B-cell development is inhibited by the dominant negative helix loop helix factor Id3. Blood 94: 2637-2346, 1999.

18. Jazag A, Ijichi H, Kanai F, Imamura T, Guleng B, Ohta M, Imamura J, Tanaka Y, Tateishi K, Ikenoue T, Kawakami T, Arakawa Y, Miyagishi M, Taira K, Kawabe T and Omata M: Smad4 silencing in pancreatic cancer cell lines using stable RNA interference and gene expression profiles induced by transforming growth factor-beta. Oncogene 24: 662-671, 2005.

19. Ammanamanchi S and Brattain MG: Restoration of transforming growth factor-beta signaling through receptor RI induction by histone deacetylase activity inhibition in breast cancer cells. J Biol Chem 279: 32620-32625, 2004.

20. Zhang HT, Chen XF, Wang MH, Wang JC, Qi QY, Zhang RM, Xu WQ, Fei QY, Wang F, Cheng QQ, Chen F, Zhu CS, Tao SH and Luo Z: Defective expression of transforming growth factor beta receptor type II is associated with $\mathrm{CpG}$ methylated promoter in primary non-small cell lung cancer. Clin Cancer Res 10: 2359-2367, 2004.

21. Ogawa M, Yamamoto H, Nagano H, Miyake Y, Sugita Y, Hata T, Kim BN, Ngan CY, Damdinsuren B, Ikenaga M, Ikeda M, Ohue M, Nakamori S, Sekimoto M, Sakon M, Matsuura N and Monden M: Hepatic expression of ANG2 RNA in metastatic colorectal cancer. Hepatology 39: 528-539, 2004.

22. Eguchi H, Nagano H, Yamamoto H, Miyamoto A, Kondo M, Dono K, Nakamori S, Umeshita K, Sakon M and Monden M: Augmentation of antitumor activity of 5-fluorouracil by interferon alpha is associated with up-regulation of p27Kip1 in human hepatocellular carcinoma cells. Clin Cancer Res 6: 2881-2890, 2000.

23. Watts GF, Albano JD, Bennett JE, Morris RW, Shaw KM and Polak A: Assessment of new radioimmunoassay kit for determining urinary albumin at low concentrations: comparison with radial immunodiffusion. J Clin Pathol 39: 1151-1154, 1986.

24. Kimachi T, Hori Y and Ikawa S: Determination of AFP and CEA by SphereLight 180. Jpn J Med Technol (in Japanese) 49: 1037-1040, 2000.

25. Yamagata Y, Shimizu K, Nakamura K, Henmi F, Satomura S, Matsuura S and Tanaka M: Simultaneous determination of percentage of Lens culinaris agglutinin-reactive alpha-fetoprotein and alpha-fetoprotein concentration using the LiBASys clinical auto-analyzer. Clin Chim Acta 327: 59-67, 2003.

26. Taketa K, Sekiya C, Namiki M, Akamatsu K, Ohta Y, Endo Y and Kosaka K: Lectin-reactive profiles of alpha-fetoprotein characterizing hepatocellular carcinoma and related conditions. Gastroenterology 99: 508-518, 1990.

27. Aoyagi Y, Suzuki Y, Isemura M, Nomoto M, Sekine C, Igarashi K and Ichida F: The fucosylation index of alpha-fetoprotein and its usefulness in the early diagnosis of hepatocellular carcinoma. Cancer 61: 769-774, 1988.
28. Midorikawa Y, Tsutsumi S, Taniguchi H, Ishii M, Kobune Y, Kodama T, Makuuchi M and Aburatani H: Identification of genes associated with dedifferentiation of hepatocellular carcinoma with expression profiling analysis. Jpn J Cancer Res 93: 636-643, 2002.

29. Ling MT, Wang X, Tsao SW and Wong YC: Down-regulation of Id-1 expression is associated with TGF beta 1-induced growth arrest in prostate epithelial cells. Biochim Biophys Acta 1570: 145-152, 2002.

30. Kang Y, Chen CR and Massague J: A self-enabling TGFbeta response coupled to stress signaling: Smad engages stress response factor ATF3 for Id1 repression in epithelial cells. Mol Cell 11: 915-926, 2003.

31. Bedossa P, Peltier E, Terris B, Franco D and Poynard T: Transforming growth factor-beta 1 (TGF-beta 1) and TGF-beta 1 receptors in normal, cirrhotic and neoplastic human livers. Hepatology 21: 760-766, 1995

32. Idobe Y, Murawaki Y, Kitamura Y and Kawasaki H: Expression of transforming growth factor-beta 1 in hepatocellular carcinoma in comparison with the non-tumor tissue. Hepatogastroenterology 50: 54-59, 2003.

33. Fausto N, Laird AD and Webber EM: Liver regeneration. 2. Role of growth factors and cytokines in hepatic regeneration. FASEB J 9: 1527-1536, 1995.

34. Bissell DM, Roulot D and George J: Transforming growth factor beta and the liver. Hepatology 34: 859-867, 2001.

35. Lee TK, Man K, Ling MT, Wang XH, Wong YC, Lo CM, Poon RT, Ng IO and Fan ST: Overexpression of Id-1 induces cell proliferation in hepatocellular carcinoma through inactivation of p16INK4a/RB pathway. Carcinogenesis 24: 1729-1736, 2003.

36. Desprez PY, Hara E, Bissell MJ and Campisi J: Suppression of mammary epithelial cell differentiation by the helix-loop-helix protein Id-1. Mol Cell Biol 15: 3398-3404, 1995.

37. Hara E, Yamaguchi T, Nojima H, Ide T, Campisi J, Okayama H and Oda K: Id-related genes encoding helix-loop-helix proteins are required for G1 progression and are repressed in senescent human fibroblasts. J Biol Chem 269: 2139-2145, 1994

38. Lin CQ, Singh J, Murata K, Itahana Y, Parrinello S, Liang SH, Gillett CE, Campisi J and Desprez PY: A role for Id-1 in the aggressive phenotype and steroid hormone response of human breast cancer cells. Cancer Res 60: 1332-1340, 2000.

39. Kleeff J, Ishiwata T, Friess H, Buchler MW, Israel MA and Korc M: The helix-loop-helix protein Id2 is overexpressed in human pancreatic cancer. Cancer Res 58: 3769-3772, 1998.

40. Le Jossic C, Ilyin GP, Loyer P, Glaise D, Cariou S and GuguenGuillouzo C: Expression of helix-loop-helix factor Id-1 is dependent on the hepatocyte proliferation and differentiation status in rat liver and in primary culture. Cancer Res 54: 6065-6068, 1994.

41. Yasuda I, Shiratori Y, Adachi S, Obora A, Takemura M, Okuno M, Shidoji Y, Seishima M, Muto Y and Moriwaki H: Acyclic retinoid induces partial differentiation, down-regulates telomerase reverse transcriptase mRNA expression and telomerase activity, and induces apoptosis in human hepatoma-derived cell lines. J Hepatol 36: 660-671, 2002. 